\title{
Compositional Planning of Residential Outdoor Space in Courtyards
}

\author{
Una Īle, Latvia University of Agriculture
}

\begin{abstract}
The aim of the article is to evaluate the solutions to residential outdoor territory planning for the 21st century residential area courtyards in Riga. Applying the comparative method to the research, several residential outdoor spaces have been analysed according to their compositional planning solutions and their elements. Consequently, the research studies the relation between the scale and spatial forms of the residential area courtyards that form the residential area with the compositional elements - forms, proportions, colours, contrasts, nuances, rhythm etc.
\end{abstract}

\section{KEYWORDS: compositional planning, elements, outdoor space.}

The conception of composition is borrowed from Latin where it means a link, connection. In the process of composition creating, it has to be taken into consideration the size, mass, pattern, geometrical form, layout, colours and shadows of the objects. Solidarity, proportions, perspectives, laws of the line composition, symmetry, asymmetry, contrast, shades, rhythm, scale and many other details are significant, as well [1]. Evaluating the relations of scale and landscape form, it is necessary to notice that the properly chosen scale and proportions is the guarantee for appropriate perception of the landscaped spatial composition, for encoding the conception of the idea [5]. The structure of the composition is visually illustrated in the scheme (Figure 1). In every situation the residential housing and its outdoor territory compositional planning is of great importance. The research has established that different elements in the outdoor territory composition need to be mutually harmonious in colour, forms and shapes, and scale,

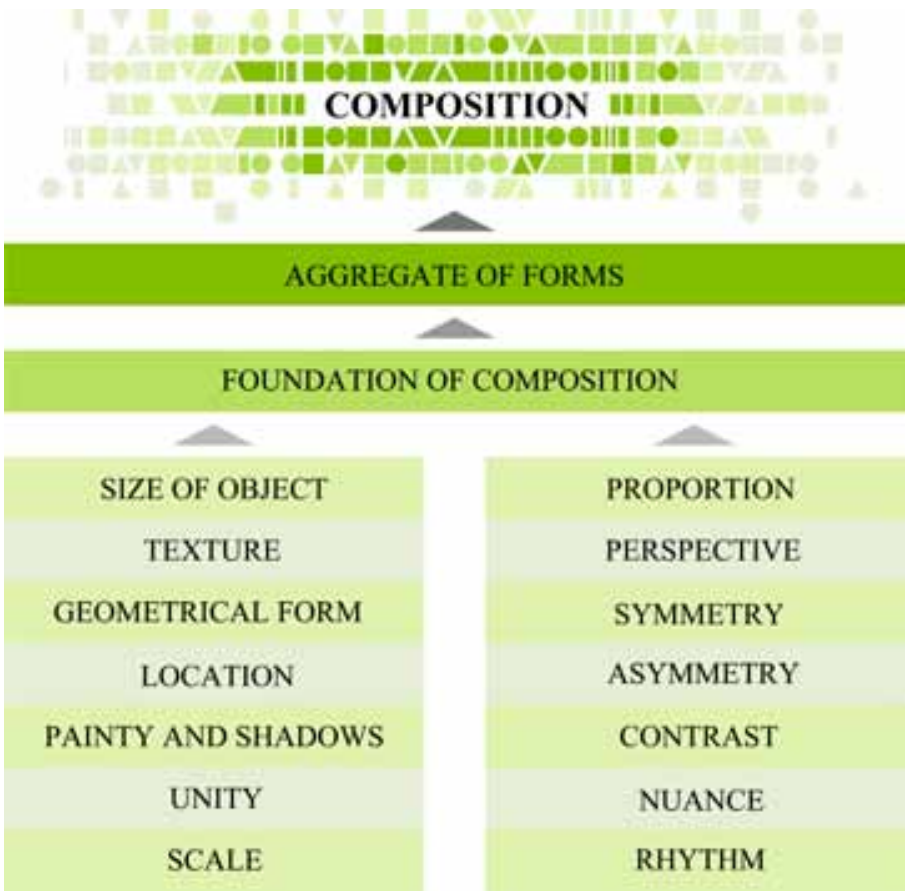

Fig. 1. The scheme of compositional structure. in order to form a balanced and well planned residential outdoor space; thus, providing pleasant exploitation possibilities of the residential outdoor space for every inhabitant. The research excludes the study of solutions to planning residential outdoor territory composition from the ecological perspective; therefore, this issue can be studied in further researches.

Our delight of the landscape composition depends on the fact whether we appreciate alignment and interaction of its elements. Such order necessarily has to consist of the similarities of the physical characteristics of the elements or harmonious interaction of its interspace, i.e. different objects in composition have to be harmonious in colour, form or pattern or in harmonious similarity in respect to sequence recurrence and balance. Speaking subjectively, delight is based on pleasant interest interrelation created by different features. Recurrence, sequence and balance, which make order in the composition, in this respect are not only the recurrence, sequence and balance of objects or characteristics, but awake interest to all of them [7]. The region of Riga develops faster than other regions of Latvia; therefore, undesirable facts summoned by uncoordinated development and threats are expressed there harder than in other places [8]. Consequently, this article studies the large-scale residential areas of Riga, built in the 21 st century, and their residential outdoor space from the perspective of compositional planning.

\section{Elements of Compositional Planning in the Residential Outdoor Space}

In the landscape composition, our attention is paid to the object because of its form. Relation among the elements creating the form could be so ordinary, so obvious, so easy to understand that we instantly like the object set, in such a way like single separate quiddity. Or its form is directly that we have known for a very long time; therefore, it can take our interest, because we are used to see it and because it has more associations in our minds [7]. Some are human fabrications, while others are abstracted from natural elements. Among the many possibilities, the most rudimentary shapes are the square, triangle, and circle [3]. The topic is about the object location in relation to other objects and observer. Arranging objects in space frontal, spatial and deeply spatial composition could be created $[1,7]$. Relative force with the help of which different objects of composition will pay attention to them, observer feels intuitively, is a very important aspect in every planning. Since spatial compositions are large, it is less possible to perceive viewpoints; as well brain memory abilities are more significant in the achievement of the total composition effect. The same refers to the style and characteristics, as well as to the unity and perfection of emotional effect. Landscape composition can satisfy even if it creates a wider visual area than it could be included in a figurative unit. There could be three - dimensions, 
plan organization and intuitive memory provoked by features of location [7]. Such spaces fit for an individual function, a place of restrained emphasis, and / or as one space among others. Their simplicity makes them easily recognized and understandable, thus providing a feeling of familiarity and comfort [3].

The latest residential building standard designs in Latvia, which allow freer rearrangement of separate sections, provide the possibility to split the total scale of the building and this way to create the subordination of divided space and its element scale in new residential areas. In every particular situation the image of the building and surrounding outdoor territory is very important to the courtyard. When perceiving spatial environment, forms and proportions of objects are important as visual images through mediation of which we get information both about the essence and correlations of these objects, and space type, measures, proportions [14]. Information that reflects architectonically organized environment and objective qualities of its separate forms not only gives necessary knowledge that helps to orientate in the increasing variety of spatial forms, but rather substantially affects our emotions [12]. The sense of proportions comparing with scale sense is considered to be the result of qualitative development of psyche, where in addition to hereditary information opinions become important, which are gained as a result of life experience about environment and its individualities, art, culture, its different expressions, as well as social life in its various forms. From the informative point of view, the most characteristic and easy perceived features are silhouette and plastic formation [5]. In general cases, common spatial construction originality depends on the silhouette of spatial system (lines) - vertical culmination of the composition, on the planning (horizontal mass composition) and on the plastic formation referring both to the form (form system) in common, and its separate elements [12]. There are innumerable forms that the landscape architect can employ to mold exterior space [3]. Space perception and composition are two different conception groups that have corresponded so far with a few interrelated fields of problems, researches and opinions. On the one hand, it is human psychophysiology, but on the other - subject environment with traditional elements of its composition - form, proportions, colour, etc. [14]. Thus, the most significant disadvantages created because of the weak spatial structure often are not noticed till the moment that it is already too late to change something [2]. In turn, the features of plastic formation more clearly come to the light in inhomogeneity and dynamics of the spatial structure, as well as in the lights and darks game of surfaces. Therefore, in the dominant form of environment perception - in movement - silhouette and plastic formation are the most capacious and emotionally the most active information parts [5]. Urban residential areas are the first communication space that children enter society. Recreational sites are integral part of urban residential areas. In the specific planning and design, they are often ignored or made for adults [15]. Trying to define the term of rhythm, very many and various explanations of the conception "rhythm" are at the interface. The origin of Greek conception rhytmos (rhythm) is connected with the verb rhëo (to stream/ to flow). Any perceptible form existing in the fluency of time process flow is one of the formal fundamental principles [6]. On the level of modern residential area courtyards,

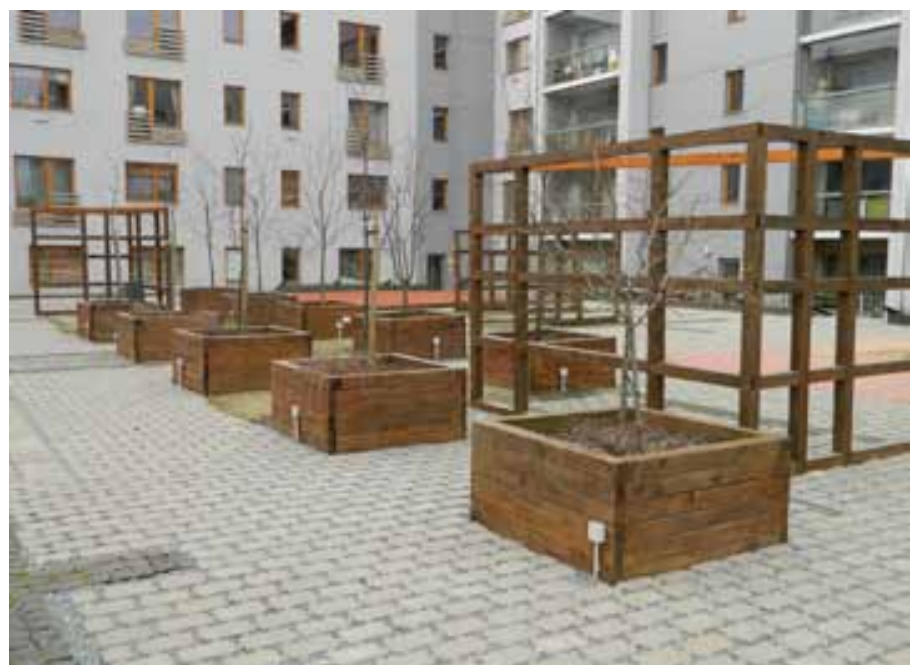

Fig. 2. Tree boxes located in a certain rhythmic pattern in the residential outdoor space in "Dienvidu Pakavs I" ("The Southern Horseshoe I"), Vienības gatve, Riga, Latvia, 2012. [16]

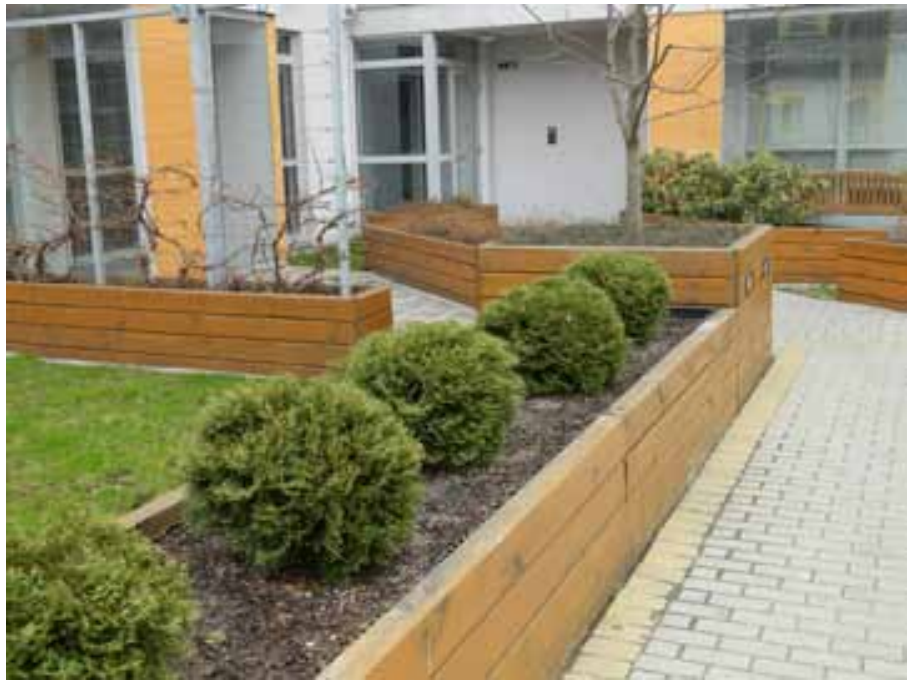

Fig. 3. Rhythmically planned greenery with evergreen plants in a residential outdoor space in "Ziedondārza mājas", A. Čaka iela, Riga, Latvia, 2012. [16]

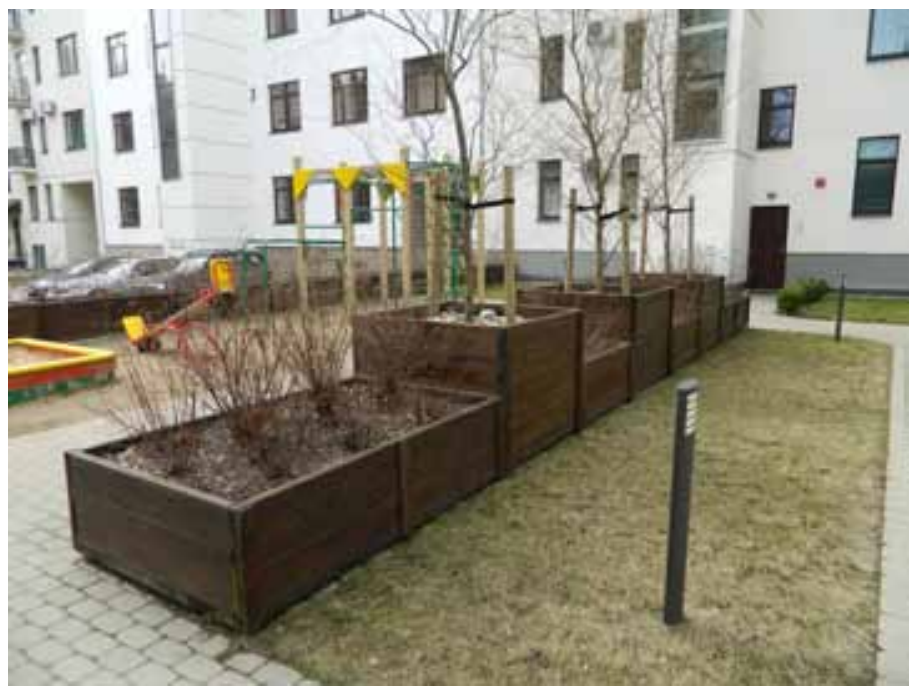

Fig. 4. Example of residential outdoor space landscape solutions in "Tomsona terases", Tomsona iela, Riga, Latvia, 2012. [16] 


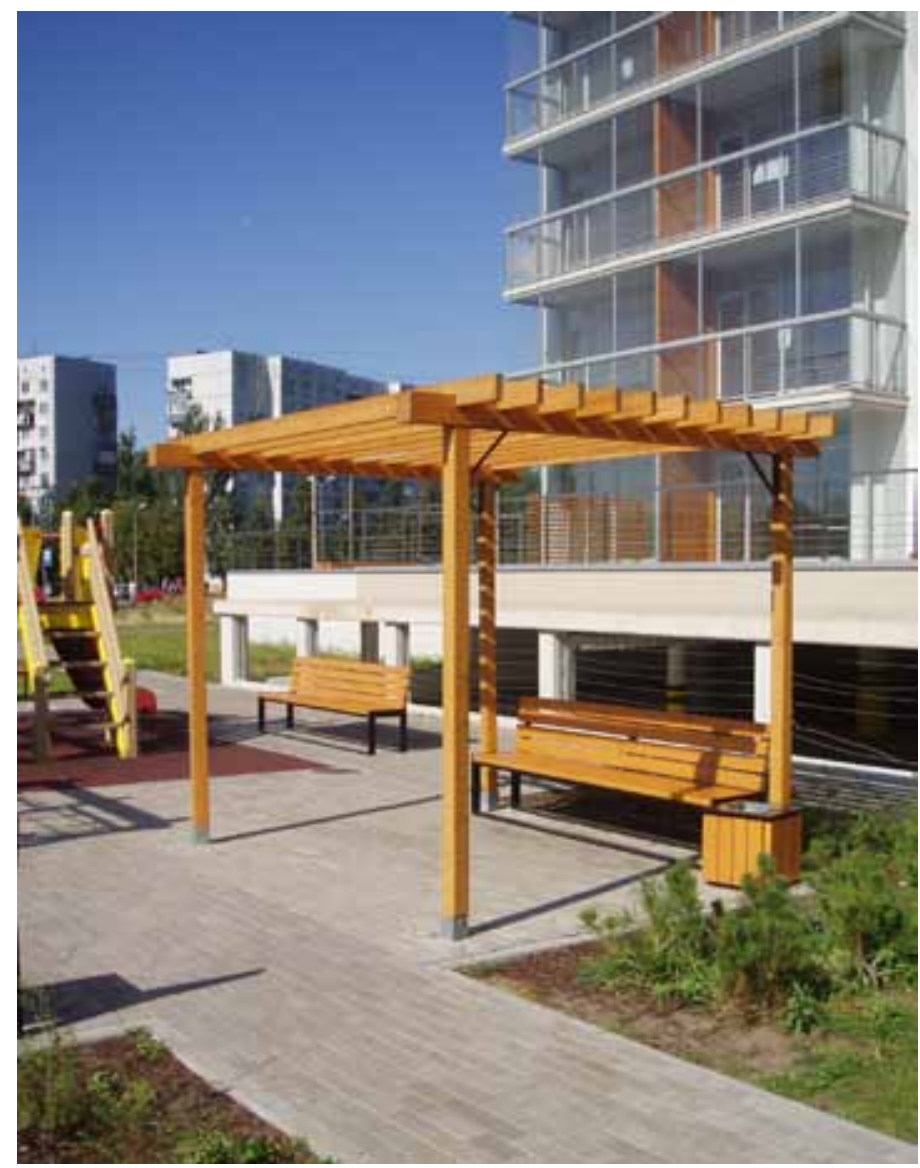

Fig. 5. Example of landscape for a resting area in the residential area in Imanta, Riga, Latvia, 2010. [16]

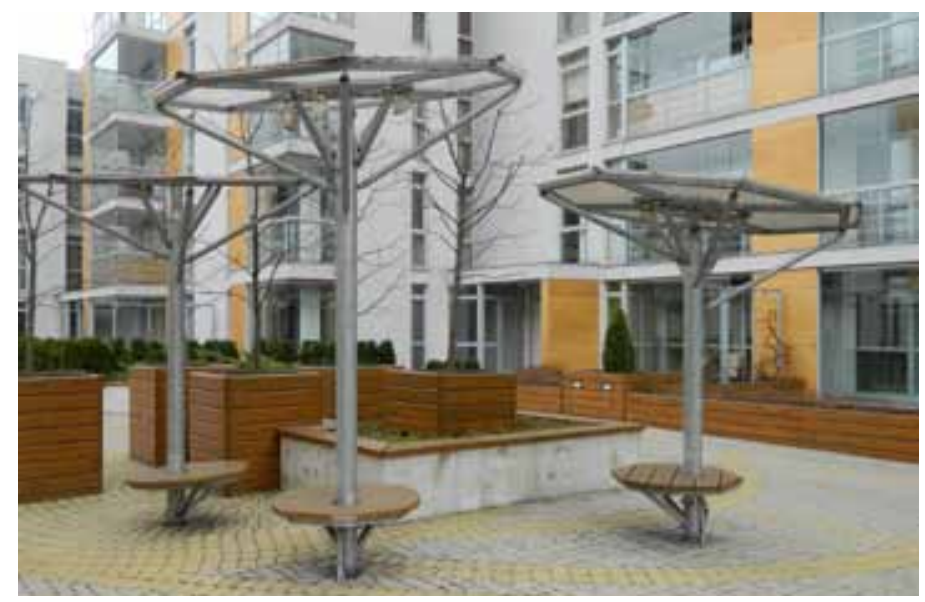

Fig. 6. Examples of resting area in "Ziedoṇdārza mājas", A. Čaka iela, Riga, Latvia, 2010. [16]

rhythm in spatial space expresses itself variously, for example, rhythmical location of public outdoor territory landscaping elements and installation in the outdoor residential territory; it is visually illustrated in the scheme of the Figures 2, 3. Thus, recurrence is the most important of the order forms and is the element that appears most frequently. To achieve the harmony, there has to be principle of recurrence, it can also be a sequence and balance in form, colour, material, structure. Satiated recurrence comes to the exaggeration and monotony. Its opposition variety is not always the best solution. Variety is not the principle of

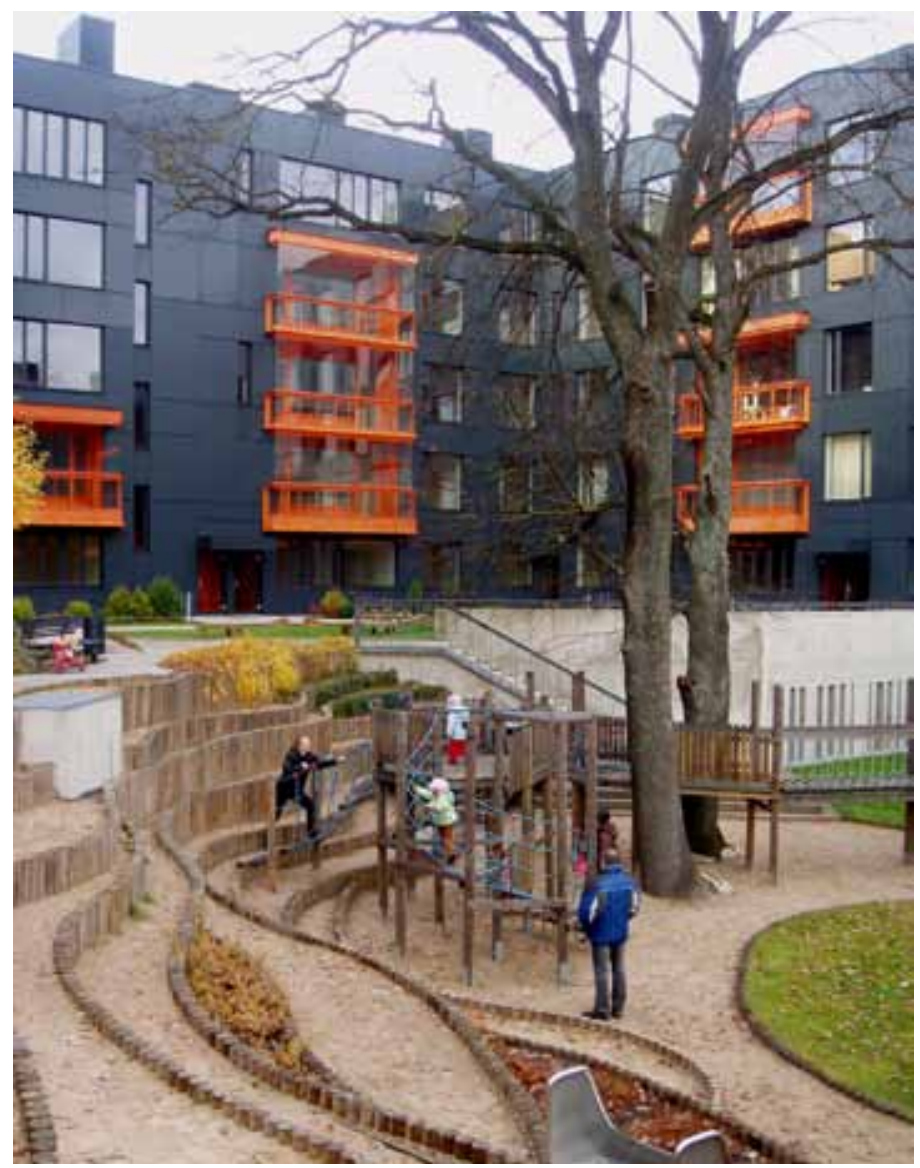

Fig. 7. Children playground in "Dienvidu Pakavs II" ("The Southern Horseshoe II”), Vienības gatve, Riga, Latvia, 2011. [16]

organisation, though, pleasant emotions gained by its existence is the human mind organisational principle. Courtyard landscape spatial planning designs are multitudinous, visually illustrated in the Figures 4-6. When considering colouristic structure of composition, most important is sequence of tones. Every surface has its own effect in composition, determined by light and its reflections. Differences are observed: tone differences, intensity differences of tone depth and impact of the light intensity on the eye [7].

\section{Examples of Landscape in the Residential Outdoor Space}

It has to be noted that landscape architecture as one of the important territorial environmental planning elements develops on the basis of progressive functional, economical and aesthetical factors. It solves the development of human private living space quality in the widest urban development aspect. The projects of landscape architecture are integral, as well as impellent territorial environmental planning part $[4,13]$. By considering these factors in the large-scale residential areas of Latvia, the landscape space in courtyards would improve step by step. It would be a pity if the multilateral experience gained in the past few years on the projecting and building of houses appropriate to the conditions of Latvia were wasted, and the standstill time in apartment building area lasted [8]. The residential building complex "The Southern Horseshoe" in Riga, region of Ziepniekkalns, can be mentioned as one of the qualitative examples of residential area planning. 


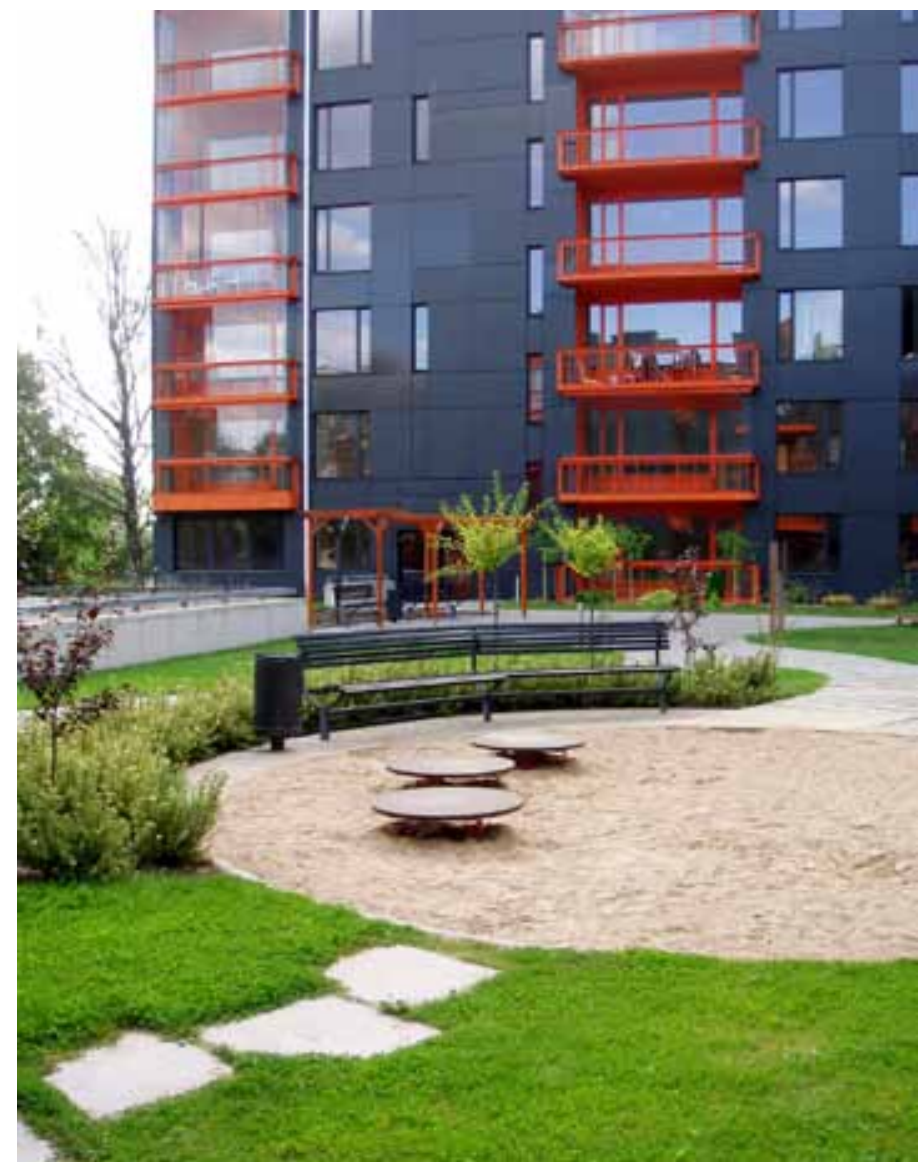

Fig. 8. Children playground for younger children in "Dienvidu Pakavs II", Vien̄ibas gatve, Riga, Latvia, 2011. [16]

In case if the first occasional visions of developer were implemented, then the present and typical building landscape of Ziepniekkalns, i.e. nine-storey and twelve-storey buildings of Series 119, would be supplemented with some more impersonal residential and office towers. Architects managed to convince the customer of circumferential or horseshoeshaped building advantages, of the necessity for the rebirth of Ziepniekkalns, of human scale and qualitative public outdoor territory improvement, without losing customer economically grounded indicators and the ones determined by urban building regulations: numbers of square metres, price of square metres, selling possibilities and building density, insolation, etc. The quality of the residential outdoor territory is not just bare developer's concern for the city, but it is a thought-out part of the functionally aesthetical common image in the courtyard $[11,9]$. The courtyard territory is freely available to the pedestrians of the neighbouring buildings; its double-level planning creates a special feeling of private territory, and the secret of the outdoor territory comes out only in the close-up. Changes of colour levels in the residential outdoor territory logically distinguish two playing zones - for smaller and older children, visually illustrated in the Figures 7-8. Almost all children requirements have been thought out there: to crawl, to climb, to slide, to draw and to form, but one very important is missing - to swing. Berry bushes, fruit-trees at the children sandboxes reveal the latest world tendencies. Along with autumn leaf drop, the issue about the upkeep of steep terrace could become particularly topical.

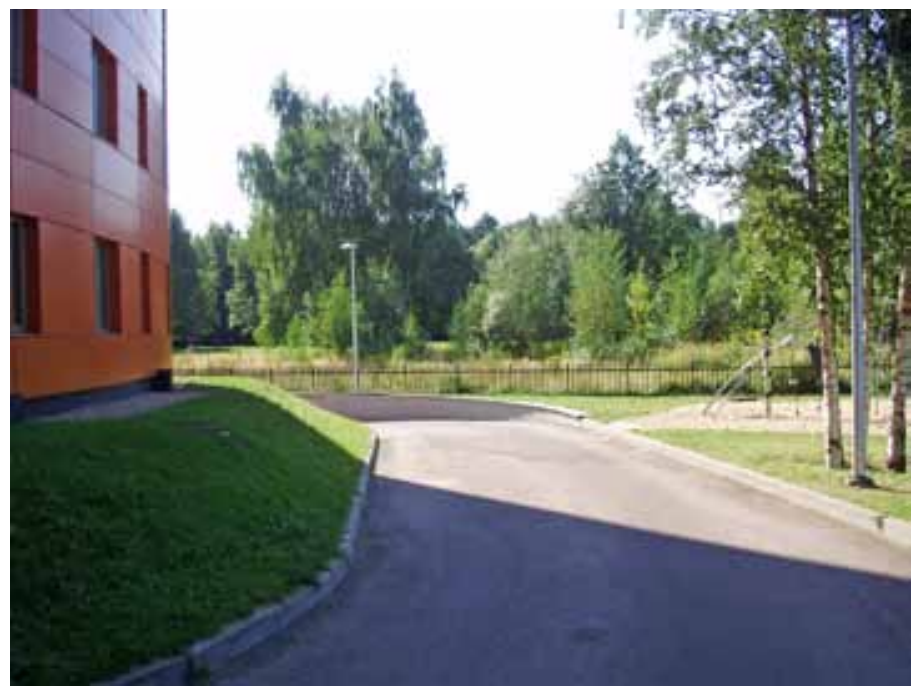

Fig. 9. Children playground for residents located near the underground parking lot in Imanta, Riga, Latvia, 2011. [16]

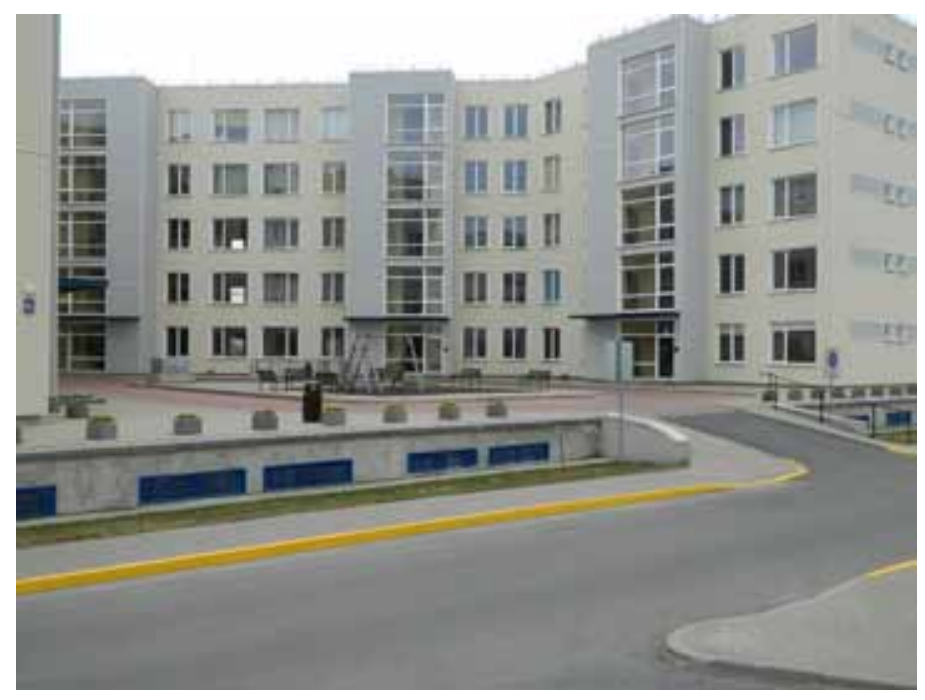

Fig. 10. Resting area without greenery zones in Biḳernieku iela, Riga, Latvia, 2012. [16]

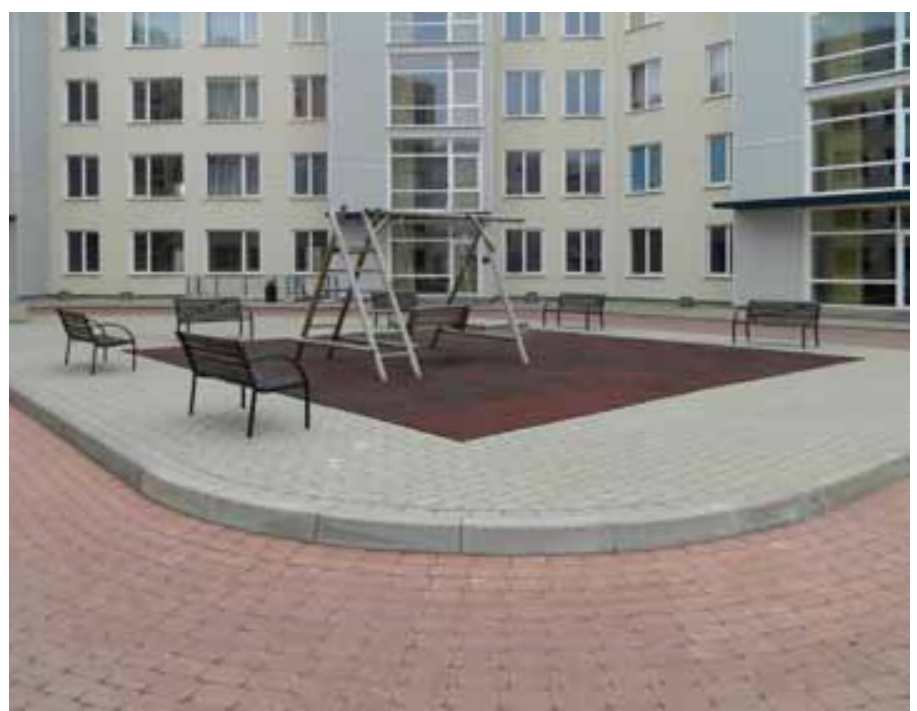

Fig. 11. Example of residential outdoor space planning in Bikernieku iela, Riga, Latvia, 2012. [16] 


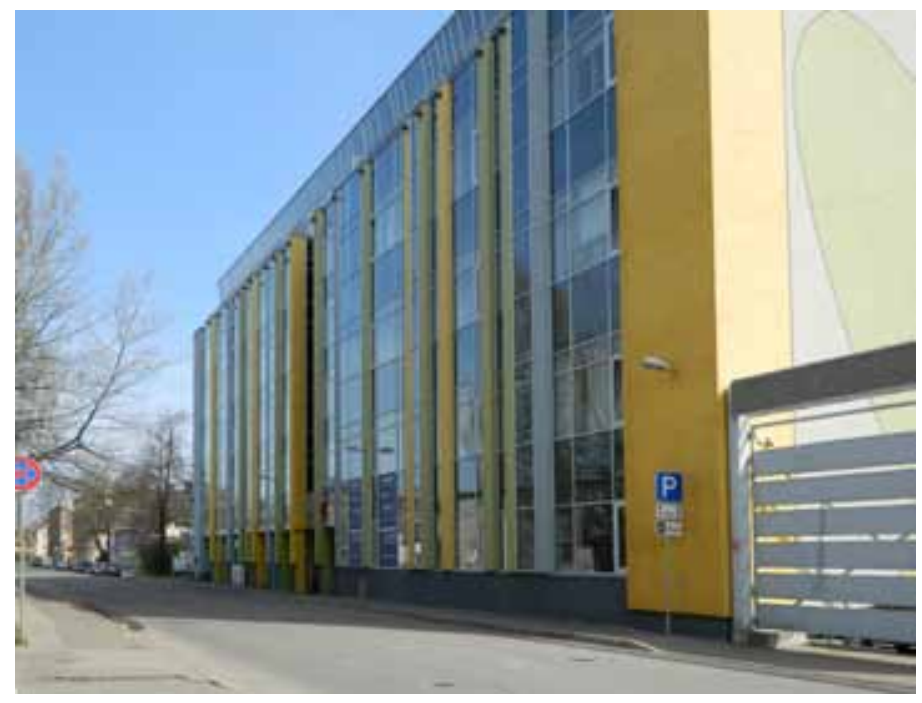

Fig. 12. Former flour warehouse "Druva", which was transformed into a largescale residential housing, Rūpniecības iela, Riga, Latvia, 2012. [16]

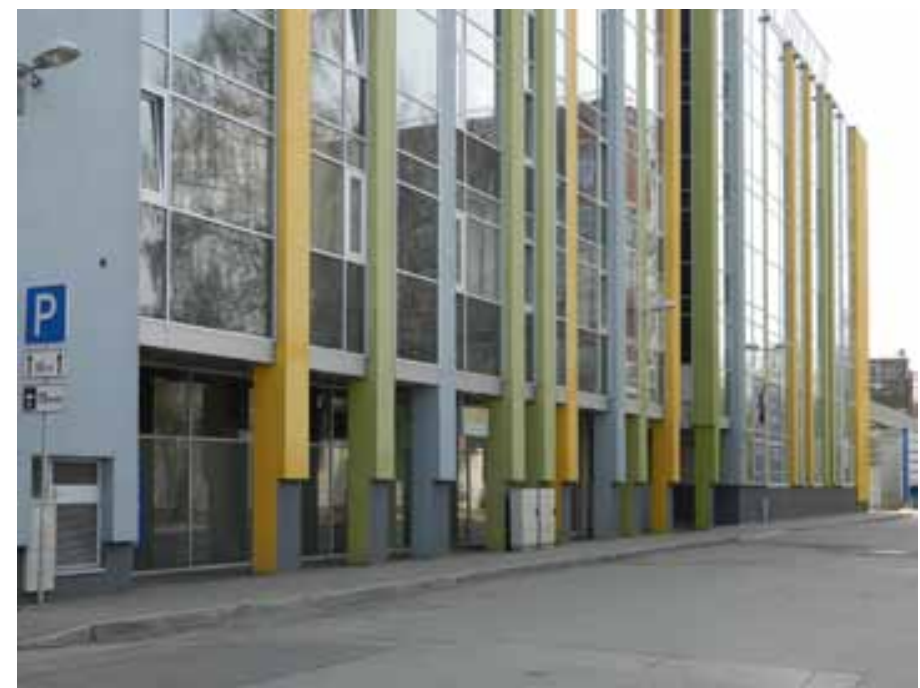

Fig. 13. Large-scale residential housing area courtyards in Riga, Rupniecības iela, Riga, Latvia, 2012. [16]

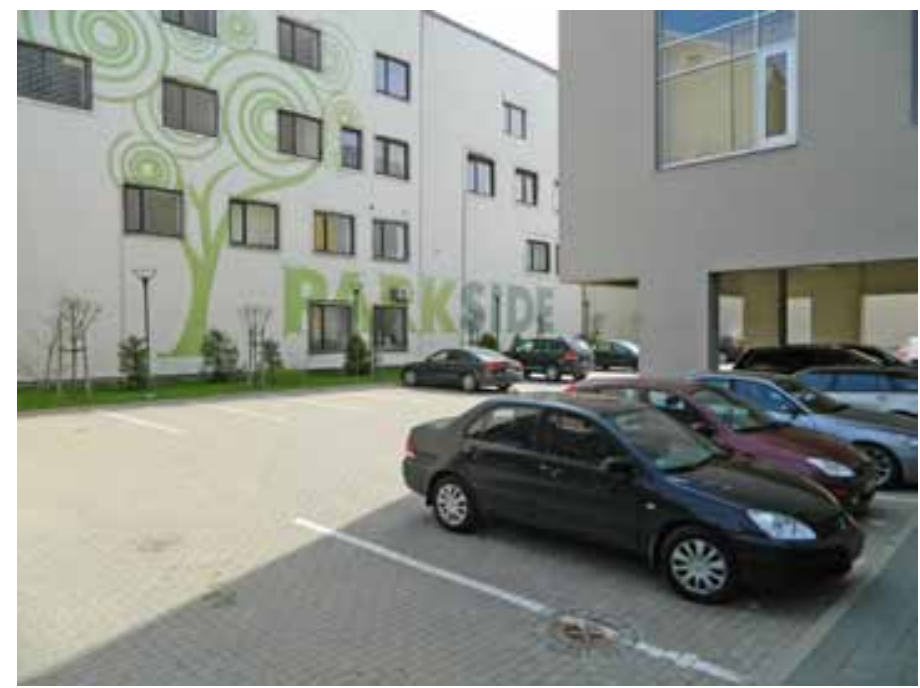

Fig. 14. Example of residential outdoor space without a planned area for children playground, Rupniecības iela, Riga, Latvia, 2012. [16]
There are not places provided for motor vehicles in the courtyard planning - parking lots are located underground, which is a modern and ecological solution concerned with children safety and health. In both projects "Southern Horseshoe I" and "Southern Horseshoe II", thanks to the architects' jobs well done, the preserved trees have become the central elements of the courtyard - Quercus (oak trees) and Tilia (lime trees) [11].

Particular difference of the residential building territory set at the beginning of the 21 st century from the former residential building territory is the request for at least one parking place for each apartment. Besides, a developer has to accomplish this request within his land plot. If the whole courtyard is built: it is possible to locate parking lots both underground, and overground, and in a separate multi-storey building. If one building is built, then the number of apartments there practically depends on the number of parking places; courtyard as a parking lot and obligatory children playground on the corner of the land plot, visually illustrated in the Figures 9-11. In case of the underground parking lot-relevant rise in price of the building and improvement without trees. In turn, partly deepened underground parking lots under the plot part create so far unfamiliar designs in vertical planning. When buying the apartment, a purchaser is used to decline expensive underground parking place and keep the car in the street. The solution would be - planning the parking facilities for motor vehicles close to the living places in complex with the urban development plan and other citizens' needs: health centres, schools and kindergartens, instead of diverting them to occasional objects [8]. The transformation of the former factories into the residential or office buildings (it is not a novelty today, but logical development - industrialization in the centre of the city is neither economically, nor ecologically grounded). It has been found out in the research that often the idea about children playground in the courtyard is missing in such designs, where only narrow utilitarian necessity is solved - parking lots, visually illustrated in the Figures 12-13. Therefore, this fact outlines negative trends. Exactly organised outdoor territories in housing areas facilitate communication among the groups of local residents [10]. In turn, it is a very necessary aspect in a modern chaotic life rhythm to make new social connections.

\section{CONCLUSIONS}

The research established that the residential outdoor territories planned and built in the 21 st century in Riga are very diverse, which is approved by the examples selected. The analysed examples of the residential outdoor spaces accentuate those issues that where either neglected in the whole primary projecting process, or were not completely finished in the final building process. As a result, such territories, where multiple inconsistencies have been detected, are posing discomfort and lack appropriate greenery systems and good recreational areas for the territory residents. The greenery areas are minimal or absent; the residential outdoors are made up of the asphalted parking lots and mass built paved concrete paths that with their visual appearance diminish the desire of the residents to spend their time in these territories. As a result, looking from the relation of the spatial shapes in the residential area courtyards that makes up this residential outdoor space with different compositional elements, these territories can 
be characterised as formal and often practically unexploitable for recreational possibilities for residents. It means that the image of every residential outdoor space affects the residents' desire to spend their time in these territories, and looking from the mutual relation between the shapes in these compositions, they do not provide the planned effect, if they are not functionally useful for the residents to spend their free time.

An appropriate and functional approach to planning residential outdoor territory composition is one of the most important factors for the territory inhabitant to feel comfortable and pleasant in its area of residence. The harmony in the residential area is based on the functional and aesthetically qualitative solutions to compositional planning in courtyards.

\section{REFERENCES}

1. Ainavu dizaina pamatprincipi [tiešsaiste]. Arhitektūras un celtniecības aǵentūra [skatīts 18.04.2012.]. http://lv.lv.allconstructions.com/portal/ categories/303/1/0/1/article/1425/ainavu-dizaina-pamatprincipi

2. Bertaud, A. Note on Riga Spatial Structure [skatīts 18.04.2012.]. http://alainbertaud.com/images/Note_on_Riga_Spatial_Structure_Rev.pdf

3. Booth, N. Foundations of Landscape Architecture: Integrating Form and Space Using the Language of Site Design. New Jersey: John Wiley \& Sons, 2012, p. 5-74.

4. Bringkis, J. The Main Trends in the Transformations of the Functional and Architectural - Spatial Structures of the Populated Areas of Latvia Architecture and Construction Science (Scientific Proceedings of Riga Technical University, Series 2). Rīga: RTU, 2004, Vol. 5, p. 26-29.

5. Bringkis, J. Architectural and Spatial Aspects of Regional Development Architecture and Urban Planning (Scientific Journal of Riga Technical University, Series 10). Rīga: RTU, 2007, Vol. 1, p. 101-108.

6. Grišins, V. Rhythm and Architecture. Architecture and Construction Science (Scientific Proceedings of Riga Technical University, Series 2). Rīga: RTU, 2001, Vol. 2, p. 49-54.

7. Hubbard, H. V. Landscape composition. An Introduction to the Study of Landscape Design. USA: Read Books, 2010. p. 88-129.

8. Krēgers, I. Brīnuma sausais atlikums. Latvijas Arhitektūra, 2009, Nr. 84, 76.-78. lpp.

9. Ķempe, I. Jaunlaiku darbarūḳu mājiṇas. Latvijas Arhitektūra, 2009, Nr. 83, 40.-43. 1pp.

10. Rukšāne, I. „Park Side” Rūpniecības ielā. Latvijas Arhitektūra, 2009, Nr. 85, 40.-44. lpp.

11. Rukšāne, I. Ziepniekkalna pārvērtības. Latvijas Arhitektūra, 2009, Nr. 82, 20.-26. 1pp.

12. Strautmanis, I. Dialogs ar telpu. Rīga: Liesma, 1977, 25.-127. lpp.

13. Strautmanis, I. Māksla arhitektūrā. Rīga: Liesma, 1982, 71.-86. lpp.

14. Šusts, V. Telpas uztvere un kompozīcija. Rīga: Zvaigzne, 1979. 127 lpp.

15. Xiao, Z., Gong, W., Hao, L. Study on children's outdoor recreational site design in urban residential areas. Advanced Materials Research : 2nd International Conference on Structures and Building Materials, Hangzhou, China, March 9-11. Hangzhou ,2012, Vol. 450-451, p. 995-998.

16. Photo by Una İle.

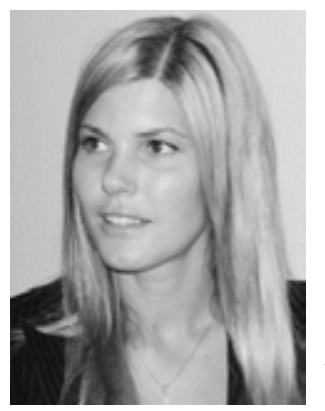

Una Īle, Landscape architect (2006). Master of Science in Landscape architecture (2008). Doctor of Architecture in Landscape Architecture sub-sector (2011).

Docent (since 2012) at the Faculty of Rural Engineers, Department of Architecture and Construction of the Latvia University of Agriculture. Publications:

- $\quad$ İle, U. Guideline for development of landscape spatial composition of the residential areas. Annual 16th International Scientific Conference Proceedings : Research for Rural Development 2010. Jelgava: PERI, 2010, p. 169-173. ISSN 1691-4031.

- İle, U. Principles for planning residential area greenery. Annual 17th International Scientific Conference Proceedings : Research for Rural Development 2011. Jelgava: PERI, 2011, p. 182-188. ISSN 1691-4031.

- Ile, U. Landscape composition development stages in multi-storey residential areas of the Baltic Sea region. Science - future of Lithuania. Vilnius: Vilnius Technika, 2011, Vol. 3, p. 16-22. ISSN 2029-2341.

- İle, U. The Aesthetic Quality of Landscape Composition in the Multi-storey Residential Areas. Ilgtspēj̄̄̄ga telpiskā atț̄stība (RTU zinātniskie raksti : 14. sērija). Rīga: RTU, 2011, 3. sējums, 108.-114. lpp. ISSN 1691-6174.

- İle, U. Development tendencies of landscape composition in the urban residential areas of Latvia. Civilengineering '11. Jelgava: LLU, 2011, p. 193-201. ISSN 2255-7776

\section{CONTACt Data}

Una Île

Dr. arch., Landscape architect

Latvia University of Agriculture

Address: Akadēmijas iela 19, Jelgava, LV-3003, Latvia

Phone: +37129185575

E-mail: unaile@1lu.lv 